\title{
Analyzing the Unreliable Narrator: Repetition and Subjectivity in Raymond Carver's "What Do You Do in San Francisco?"*
}

\author{
Huda Al-Mansoob \\ Ibb University, Yemen \\ Email: halmansoob@yahoo.com
}

\begin{abstract}
The focus of this paper is on a further investigation into the growing area of research in the idea of unreliability in literary studies. The paper seeks to examine the issue of unreliability with reference to Raymond Carver's seminal short story "What Do You Do in San Francisco?" The first part of the paper provides an overview of the contrasted key theoretical investigations into the concept of unreliability, and in the second part, I have made an analysis of Carver's story by applying the ideas of unreliability, mainly A. Nünning's cognitive model. Even with the publication of Booth's (1961, [1983]), narrative element assumes the central significance in narratology. In recent times, many theorists have taken issue with Booth and have even denounced some of the fundamental ideas propounded by Booth. Taking into cognizance both sides of the arguments, my paper, besides discussing the notion of unreliability, attempts a detailed analysis of Carver's narrative. In essence, the paper highlights how the foregrounded language of the surface of the story contributes to the reader's suspicion of the reliability of the narrator, thus forcing him/her to scrutinize its depth in an attempt to fathom an ample meaning.
\end{abstract}

Index Terms - unreliability, cognitive analysis, stylistics, Raymond Carver, narratology

\section{INTRODUCTION}

Taking cue from Chenetier's (qtd. in Runyon, 1992) important observation on Carver's stories that "perpetually suggest that surfaces tend to have two sides and that the one we see is not the one that matters" (p. 7), I propose to investigate how such a technique has been employed by Carver. Although most critics have taken notice of this feature, none to my knowledge, has endeavored to present a thorough analysis of Carver's stories pointing to this element. This paper is an attempt to address this argument by analyzing one of Carver's most amazing short stories "What Do you Do in San Francisco?" Deploying A. Nünning's (1998) cognitive model of unreliable narration in the story, the paper shows that the narrator's unreliability can be determined by textual signals. The reader first detects the narrator's unreliability through the textual signals based on the surface of the narrative, and then s/he moves beyond the literal meaning of the text to dig out a meaning in its depth. Interpreting the story as an unreliable narrator allows the thematic meaning of the story to be easily identified.

\section{UNRELIABILITY IN NARRATIVE}

Since Wayne Booth's introduction of the concept of unreliable narrator in 1961, it has been one of the most hotly debated issues in narratology. The idea has led several recent studies to promote a critical re-examination of the traditional understanding of the unreliable narrator. For Booth, a narrator is "reliable when he speaks for or acts in accordance with the norms of the work (which is to say, the implied author's norms), unreliable when he does not" (p. 158-159). He observes further that the "narrator is often radically different from the implied author who creates him" (p. 152). In other words, a narrator is considered to be unreliable if his remarks and expressions convey perceptions and values that deviate from those of the implied author. ${ }^{1}$ Accordingly, the notion of the unreliable narrator is seen as a "text-internal" issue between the "postulated narrator" and the implied author "(the author's 'second self')" (p. 151). Olson notes that "Booth's emphasis on the pleasures of exclusion suggests that the reader and implied author belong to

\footnotetext{
* A text world analysis for the short story, "What Do You Do in San Francisco?" was initially presented at the 2004 Poetics and Linguistics Association Conference in New York City. I am very grateful for comments and suggestions, I received on that talk from several specialists, to reanalyzed the story by using the theories of unreliability. Their suggestions have helped me to produce this paper. Also, I am especially grateful to professor Willie van Peer who always finds time to listen to my questions and for his reading and valuable comments.

1 See Kindt and Müller (2006) for a thorough discussion of the notion of the implied author. The concept of "implied author" first appeared in Wayne C. Booth's The Rhetoric of Fiction (1961[1983]) as the "core of norms and choices" in any text (p. 74). The implied author is different from the narrator in that the implied author does not narrate events or dialogue, but instead is present through ideology. The principal idea behind suggesting an implied author as distinguishable from the real author is to accommodate a sense of an authorial presence within a given literary work without being assigned directly to the real author him/herself.
} 
an in-group that shares values, judgments, and meanings from which the unreliable narrator is ousted" (p. 94). Although, Booth's definition of unreliable narrator remains the chief inspiration for narratologists, it went through further refinement and classification by a number of narratological scholars who mainly pay a considerable attention to the interrelationship between author, narrator and reader without achieving unanimous agreement (see Chatman, 1978, 1990; Cohn, 2000; Rimmon-kenan, 1983).

In recent times, several cognitive and literary theorists have raised issues with Booth's traditional definition of the unreliable narrator for its reliance on the implied author, e.g., Yacobi, Wall, Olson, Zerweek, Vera Nünning, Cohn and Hansen. Pioneer among them is Ansgar Nünning, a cognitive narrarologist, who contests the rhetorical approach, suggesting that the technique of the unreliable narration can be reinterpreted within a cognitive approach. He criticizes Booth for his view of unreliable narrator as a matter of relationship between the implied author and the personified narrator which led to the exclusion of the reader's role in the perception of the concept of unreliability. Unreliability develops in the process of reception, depending on the reader's interpretive strategies. For that reason, he proposes to renounce the notion of the implied author for its inadequate definition in support of a "reader-oriented" approach (see A. Nünning, 2008, for more discussion). He also claims that critics who rely on the notion of the implied author to detect unreliability are those whose aims are to represent their own values onto texts (Olson, 2003, p. 79). Nünning supports his argument by a research conducted by Vera Nünning (2004) who takes the cultural context into consideration and proves that the historical variability of values and norms affects our perception of the concept of unreliability, for instance, The Vicar of Wakefield's narrator Primrose was interpreted as sympathetic and trustworthy by two centuries of readers, only to have his reliability questioned during recent decades" (ibid). V. Nünning's elucidation of the concept of unreliable narration is regarded as a fundamental change towards a wider view of discernment. This is because ignoring the cultural context or ahistorical interpretation of any text will do injustice to the complexity of the concept (V. Nünning, p. 238). In V. Nünning's words:

The historical variability of values and norms, therefore, centrally affects the evaluation of unreliable narration. Since the criteria for judging what counts as "common sense", "normal," or "good" differ from epoch to epoch as well as from culture to culture, critics from different times and cultures will evaluate the unreliability of narrators differently. (ibid)

In view of that, A. Nünning posits that unreliable narration should be (re)conceptualized within the context of frame theory "as an interpretive strategy or cognitive process of the sort that has come to be known as 'naturalization"' (qtd. in Zerweek, 2001, p. 151). In fact, A. Nünning adopted the notion of "naturalization" from Culler (1975) and Fludernik (1996) which the former explains, in such terms, that "naturalization processes are reading strategies which familiarize the unfamiliar, and they therefore reduce the unexpected to more manageable proportions, aligning it with the familiar" (1996, p. 34). When readers detect any obvious contradiction or discrepancies acted or narrated by a narrator, then they can relate such contradiction or discrepancies to their frames of experiences (p. 98). Olson further mentions that:

According to theories of "naturalization" (Culler; Fludernik, Fictions and 'Natural' Narratology), readers relate what they read to ordinary human actions, motivations, and behavioral scripts. They impose their expectations about how texts should work and how people tell stories onto the text in order to make sense of it. A part of this process of fitting the text into one's worldview is identifying the narrator (if there is a clearly identifiable one) and deciding what sort of person that narrator is on the basis of one's referential frames. (2003, p. 98)

In A. Nünning's vision, unreliable narrators are not to be comprehended "as a structural nor as a semantic aspect of the textbase alone, but only by taking into account the conceptual frameworks that readers bring for the text" (qtd. in Hansen, 2007, p. 228). In the current age of increasingly rapid movements towards cognitive sphere of influence, A. Nünning's cognitive re-conceptualization of the notion of unreliable narrator represents a radical shift.

In order to simplify his interpretive strategy of how to detect unreliable narration, A. Nünning suggests a detailed list of textual signals: (1) the narrator's explicit contradictions and other discrepancies in the narrative discourse; (2) discrepancies between the narrator's statements and actions; (3) divergences between the narrator's description of herself and other characters' descriptions of her; (4) contradictions between the narrator's explicit comments on other characters and her implicit characterization of herself or the narrator's involuntary exposure of herself; (5) contradictions between the narrator's account of events and her explanations and interpretations of the same, as well as contradictions between the story and discourse; (6) other characters' corrective verbal remarks or body signals; (7) multiperspectival arrangements of events and contrasts between various versions of the same events; (8) an accumulation of remarks relating to the self as well as linguistic signals denoting expressiveness and subjectivity; (9) an accumulation of direct addresses to the reader and conscious attempts to direct the reader's sympathy; (10) syntactic signals denoting the narrator's high level of emotional involvement, including exclamations, ellipses, repetitions, etc.; (11) explicit, selfreferential, metanarrative discussions of the narrator's believability; (12) an admitted lack of reliability, memory gaps, and comments on cognitive limitations; (13) a confessed or situation-related prejudice and (14) paratextual signals, such as titles, subtitles, and prefaces (adapted from Olson, 2003, p. 97-98). However, although the theory of unreliable narration has undergone a paradigm shift towards cognitive domain, it does not escape criticism either because A. Nünning "exaggerates his difference with Booth, since the norms of the implied author are of course also arrived at through an interpretation of textual data" (D'hoker, 2008, p. 465) (see also Olson, p. 105 and Cohn, 2000, p. 307). By and large, A. Nünning's and V. Nünning's hermeneutical study of unreliable narration produces a promising package for 
a reliable analysis as it opens a world of interpretive possibility by showing us how unreliability meaning functions within a larger reading community.

Irony is also targeted within the concept of unreliable narration. Irony is a rhetorical device, in which there is a discordance between saying and doing. In A Rhetoric of Irony, Booth (1974) posits that unreliable narrator is "the butt of the ironic point" (p. 304). He proposes four steps through which a reader can elicit irony in any fictional text and hence measure out the possible existence of unreliability:

1. Reader has to reject the literal meaning, identifying a disagreement between what he reads and what he knows.

2. Reader has to try out alternative interpretations or explanations.

3. Reader makes a decision about the author's knowledge or beliefs.

4. Reader chooses a new meaning or cluster of meaning with which a reader can rest secure. (p. 11-12)

If a reader recognizes striking discrepancies between the narrator's values and those noticeable in the fictional text as a whole, then the narrator will be received as unreliable, taking him to be the focus of the text's irony. On the other hand, if the narrator is viewed as "egotistical know-it-all" who turns out to be the "butt of the joke" in his own story, then the reliability will be questionable (V. Nünning, 2004, p. 239). Olson notes that those who make sense of irony and elicit unreliability "share the insider joke and enjoy having survived the initiation ritual the text appears to require" (2003, p. 94-95). Whereas, A. Nünning claims that "unreliable narration can be explained in terms of dramatic irony because it involves a contrast between a narrator's view of the fictional world and the contrary state of affairs which the reader can grasp" (qtd. in D'hoker, 2007, p. 466). In fact, my analysis of Carver's story "What do You do in San Francisco?" will deploy A. Nünning's cognitive model which is basically a reader-oriented approach along with his constructive list of the textual signals as the main strategies for detecting the unreliability of the story's first person narrator.

\section{RAYMOND CARVER}

Carver is often acknowledged as the most influential American short story writer after Ernest Hemingway. Many critics, including Campbell, Chenetier, Facknitz, Henning, Meyer, Runyon, Saltzman, among others, have paid significant attention to Carver's surface style and structure asserting that the surface of every story tends to have two sides of meaning: one, on the surface which looks calm and ordinary, and the other, beneath the lines. Nevertheless, these critics fail to address how a reader can distinguish between these two sides of any given story or to explain the implicit involvement of any specific rhetorical indicators which could mark out Carver's technique. This is, perhaps, becuase these critics have failed to notice the issue of foregrounding (conveyed in various forms of regular patterns of pragmatic or linguistic choices, prominence and repetition) which can be seen as one of the most consistent elements in Carver's style that could assist the reader in making a distinction between the two surfaces of any given story. Another issue that those critics have overlooked is the concept of (un)reliable narration.

\section{NARRATORIAL UnRELIABILITY IN "What DO YOU Do IN SAN FRANCISCO?"}

By taking one of Carver's most interesting short stories "What Do You Do in San Francisco?" as a case study, the paper attempts to show how right from the beginning of the story, the reliability of the narrator is thrust into question. Additionally, it will be shown, how, at a certain point when regular repetition of many parts of the main narrative begins to be visible, my initial understanding of the main narrative of the story comes out to be evidently suspicious. Hence, unavoidable questions have been raised, namely, how far the narrator can be trusted upon? What is implication of this foregrounded narrative? And how does answering these two questions can reveal the thematic meaning of this rather short story?

The story "What Do You Do in San Francisco?" is basically narrated by a first person narrator, a post mail worker, who is recalling a flashback story of a young couple who moved to his neighborhood. The events of the story are presented in the past tense with some shifts to the present tense. As the narrative develops, more filtering of setting information is provided. Gradually, we receive more detailed accounts of the place where the characters live, the location of the small town, its people and its surrounding and the life style of the young couple.

The narrative of "What Do You Do in San Francisco?" is peculiar, initially, on account of its opening paragraph and the account of the story as a whole. The narrator, with a definite tone, begins his story by discharging himself from any responsibility for what he is about to narrate:

This has nothing to do with me. It's about a young couple with three children who moved into a house on my route the first of last summer. I got to thinking about them again when I picked up last Sunday's newspaper and found a picture of a young man who'd been arrested down insane Francisco for killing his wife and her boyfriend with a baseball bat [....] (Carver, 1993, p. 82, emphasis added)

Yet, right from the second paragraph, the narrator contradicts himself and begins introducing himself in a fairly long paragraph:

Henry Robinson is the name. I'm a postman, a federal civil servant, and have been since 1947. I've lived in the West all my life, except for a three-year stint in the Army during the war. I've been divorced twenty years, have two children I haven't seen in almost that long. I'm not a frivolous man, nor am I, in my opinion, a serious man. It's my belief a man 
has to be a little of both these days. I believe, too, in the value of work-the harder the better. A man who isn't working has got too much time on his hands, too much time to dwell on himself and his problems. (ibid. emphasis added)

This passage stands out from the rest of the story and appears as a surprising twist. The conspicuous contradictory shift between his statements (his claim of non- involvement in the story he is about to recall in the first paragraph and his self-portrait in the second paragraph) invites doubt worth commenting upon. Right from the very outset of the narration, the narrative discourses between these two opening paragraphs are in conflict and include a sign of a sneaking suspicion of the reliability of the narrator. Although one may say that this intuitive description of himself might seem quite innocent, it can arguably render the narrator suspect, and it can also be received as the first inkling of the narrator's mentality. Another salient feature anticipated from these two paragraphs is the utilization of the present tense structure, normally called the historical present tense. ${ }^{2}$ The narrator skillfully employs the present tense to bring in a vividness and a continuation to the present moment so that the reader will be drawn in to relive the immediacy of the narrator's narrative. Also it appears that the present tense structure is used here to put an emphasis on the preliminary parts of the narrative where the narrator wants his reader to be more focused. In the first paragraph, for instance, he wants to highlight his detachment, "this has nothing to do with me", whereas in the second paragraph, he tries to show up his identity as well as his values and beliefs (see italicized sentences). Although, the narrator's acclaimed values could unsurprisingly be true when related to real life, they come out with some reservation as to how his statement can be taken as a reliable declaration or as conveying a hidden message. This is because straight from the third paragraph the narrator strikes our attention again when he summarizes his conclusion about the events he is to narrate; the woman is undoubtedly held accountable for the trouble happening to the whole family:

I'm convinced that was partly the trouble with the young man who lived here - his not working. But I'd lay that at her doorstep, too. The woman. She encouraged it. (p. 82)

Before adding more speculation about the unreliability of the narrator, let us move to the narrator's story of the young couple. When Lee Marston and his wife, "beatnik" painters, arrive, in Arcata, at a house on the narrator's route, the narrator begins to puzzle over their life style. He repeatedly tries to get the family to change their name on the mail box; he feels uncomfortable whenever he is around the woman; the family never does unload the U-Haul trailer; the three children roam freely because of their neglected mother and rumors percolate through the community about the man being a criminal on the lam and the wife a dope addict. However, after a thorough reading of the story, I will show, in the following section, how the narrator, on the one hand, uses a number of rhetorical techniques to present his story, on the other, how these rhetorical strategies bring the narrator's account into focus and thus provide extra-textual signs to confirm his unreliability as narrator.

The readers are directly addressed a number of times throughout the narration through the pronominal shifts "you". The narrator is cautiously drawing the readers in as a strategy to actively make them into more of participants thereby securing their sympathy and support. Here are a few examples:

Beatniks, I guess you'd have called them if you'd seen them (p. 82)

You hear rumors (p. 85)

You hate to see something like that (p. 86)

You'd ever really get used to (p. 87)

A. Nünning argues that the technique of "an accumulation of direct addresses to the reader and conscious attempts to direct the reader's sympathy" signals out the narrator as unreliable. Furthermore, five portions of this rather short story emerge to be foregrounded through repetition. Such repetition comes, in fact, through repeating five key words, distributed throughout the narration, i.e. "work", "the woman/she", "the kids", "the man/he" and "the name". These repetitions seem to generate meaning and suggest interpretive possibilities that have link to the thematic meaning. Let us now look at the five portions respectively (the key words are in italics for emphasis):

[1]- The foregrounded narrative of the narrator's judgmental view of "work". Notice, the word "job" is repeated twice.

the value of work - the harder the better. A man who isn't working has got too much time on his hands, too much time to dwell on himself and his problems (p. 82)

his not working (p. 82)

she encouraged it (work) (p. 82, emphasis added)

neither of them worked (p. 82)

if you're looking for a job (p. 82)

"he's not looking for a job" she put it (p. 82)

who live here work either in the lumber mills or have something to do with the fishing industry, or else work in one of the downtown stores (p. 83)

men who don't worked (p. 83)

he was going to work in Eureka (p. 85)

if he'd just go to work now (p. 86)

they surely didn't come looking for work (p. 86)

2 For an elaborate discussion on the historical present tense, see Nessa Wolfson 1987, 1979. 
why don't you go to work and forget her? (p. 88)

what have you got against work? (p. 88)

It was work day and night, work that gave me oblivion (p. 88)

It's all work, one way or the other, and I'm always glad to have it (p. 89)

[2]- The foregrounded narrative of the narrator's obscure attitude towards "the woman/she".

she encouraged it (p. 82)

she wasn't a good wife and mother (p. 82)

I always found myself feeling awkward the few times I was around this woman (p. 83)

but she stood there with her arms crossed, cool as a cucumber (p. 84)

the woman was a dope addict (p. 85)

the husband had brought her up here to help her get rid of the habit (p. 85)

there was something funny about them - the woman, particular (p. 85)

Sallie was still talking and start to work on her painting as if Sallie wasn't there (p. 85)

she'd be fondling and kissing the kids, the suddenly start screeching at them for no apparent reason (p. 85)

one time only I had anything to do with the woman direct (p. 86)

she'd taken off the week before with somebody (p. 87)

I called out, she's no good, boy, I could tell that the minute I saw her (p. 88)

[3]- The foregrounded narrative of the ill behavior of "the kids".

It's about a young couple with three children (p. 82)

I've been divorced twenty years, have two children (p. 82)

The kids picked that moment to come flying out the front door, yelling and tearing for the end of the porch (p. 84)

There were three kids (p. 84)

the kids were carrying little sticks and hammering on the sides of the trailer (p. 84)

also the way she'd be fondling and kissing the kids (p. 85)

but the kids were always there, running in and out of the house (p. 86)

then I noticed the kids playing with it (the hose) over in the field (p. 86)

after a few days he'd taken the kids to his mother's over to a Redding (p. 87)

[4]- The foregrounded narrative of the inactive role of "the man/he".

trouble with the young man who lived here- his not working (p. 82)

the young man, I don't know what he did (p. 82)

Marston was his name (p. 83)

I thought Marston was going to jump out of his skin (p. 84)

He didn't look good at all (p. 84)

It did surprise me to see he still hadn't unloaded it (p. 84)

I saw him out in the yard again and reminded him about changing the name on the box (p. 85)

He never did change the name on the box (p. 85)

But he never did change the name on the box (p. 85)

He was ex-con on parole (p. 85)

Another story was that he had committed a crime and was hiding out here (p. 85)

None of the kids belonged to him (p. 85)

$H e$ 'd taken the kids to his mother (p. 87)

$H e$ was out there at the box every day waiting for me to hand over the mail (p. 87)

$H e$ was sitting on the porch steps smoking cigarette, waiting (p. 87)

He was suffering, though - anyone could see that (p. 87)

I was him walking up and down (p. 87)

Next day he was out there same as always (p. 88)

He didn't wait outside for me any more (p. 88)

The last time I saw him he was standing at the window calm and rested (p. 88)

The next day he was gone (p. 89)

[5]- The foregrounded narrative of the "the name". Here in this part the narrator repeatedly tries to ask the man to paint his "name" on the mailbox:

'you might want to change the name on the box.' (p. 84)

on Thursday I saw him out in the yard again and reminded him about the name on the box. (p. 84)

he never did change the name on the box (p. 85)

I'll have to change the name on that box one of these days. (p. 85)

I'll get myself a can of paint and just paint over that other name (p. 85)

But he never did change the name on the box, and after a time I shrugged and forget about it. (p. 85)

Astonishingly, a close scrutiny of these foregrounded narratives reveals unpredictable account of events which creates a sense of irony. Labov (1972) argues that repetition in narrative is effective in two senses "it intensifies a particular action, and it suspends the action" (p. 379). The rhetorical effect of the irregular repetition seems to 
foreground five different perspectives of the narrator; the hypercritical attitude towards the position of the couple as being out of work, the antagonistic attitude towards the woman, the inconsequential outlook on the behavior of the children, the repetitive reminder of changing their name on the mailbox and the intrusive outlook on the passive role of the man. The cumulative effect of the five foregrounded accounts, arguably, produced a meaning behind the surface meaning of the narration that needs to be examined for it contributes to the general interpretation. The reader who follows the preceding analysis this far will surely discern that there must be a hidden implication behind this foregrounded narrative. Short (1996) points out that:

in language, the background is what is linguistically normal - the rules, norms and expectations which we associate with a particular kind of speaking or writing; the foreground is, in large part, the portions of text or talk which do not conform to these expectations. (p. 12)

Miall and Kuiken explain that when certain words or passages in the text attract the attention of the readers and heighten their feelings, they tend to give more focus on them. This is in order to consult their feeling in an attempt to reach an appropriate interpretation (1994a, p. 337). Johnstone et al. (1994) claim that:

It makes sense to suppose that when you say the same thing again, the referential meaning stays the same. But something other than the referential meaning has changed. As an element is repeated, a history for it is created; as the context within which elements are used changes, their meaning changes. (p.12)

Also, Johnstone et al. argue that repetition creates a cognitive effect (p. 12), making it easy for the readers to work out their minds to assimilate information. If we look back at the five repeated key words within their context, it can be easily observed that the "referential meanings" of these words remain the same about "work", "woman", "the man", "name" and "kids". Although the context within which those words are used is slightly modified yet it still carries the same meaning. Hence, such repetition may appear to support the ongoing criticism that Carver deals with his characters ironically. Nesset (1995) states that Carver's characters, from the earlier to the last one, are those who are classified as unhappily estranged, out of work, disillusioned by meaningless jobs and meaningless marriages; they suffer in various degrees from alcoholism as well as bad luck and bad timing, battered by a world which typically leaves them inert and speechless on the wake of longings and fears they cannot begin to identify. (p. 2)

Carver, on the other hand, denies such criticism by saying:

I'm not talking down to my characters, or holding them up for ridicule, or slyly doing an end run around them. I'm much more interested in my characters, in the people in my story, than I am in any potential reader. I'm uncomfortable with irony if it's at the expense of someone else, if it hurts the characters. (qtd. in Gentry \& Stull, 1990, p. 185)

If this is indeed the case, then what is the function of repetition in the story under test? The repetition is presented as a series of accumulated words rematerialized with the same characteristics and with the same sustained tone throughout. Apart from the fact that repetition brings some kind of cohesion into the text, it also brings the foregrounded account of the narrator into focus keeping the reader in a state of being repeatedly informed about the same entity. It restricts the readers' attention to receive at almost the rate the narrator is intending to convey; the outcome is a production of dailyconnected events resulting from a few repeated words carrying roughly the same perspectives (see Tannen, 1987a) for a fuller discussion on similar issues). Runyon explains that Carver's style:

Seemed to say so little but somehow suggest so much. As Susan Lohafer (1992) explains 'while it might seem that we could be bored by Carver's lean style [...] we are in fact kept alert by having to look through the interstices for the meaning- and by being rewarded for doing so'. (p. 1)

The descriptions made by the narrator are presented through a certain angle. Scanning throughout the main narrative and concentrating on the emphasis of the narrator on the value of having work and contrasting this with the nature of his actual job, one can realize that there is a sense of contradiction between the two statements. Noticeably, from the events of the story, the narrator has a lot of free time on his hands that allows him to interfere in the couple's life and keep spying on them daily. This is, maybe, because of his simple work as a postman delivering letters in a small community. Moreover, it can be detected that the narrator is exaggerating about his unexplained attitude towards the woman in emphasizing that she is a negligent and uncaring mother. There is a lack of alignment between reality and the narrator's obsession for criticizing the woman. This is due to the fact that, when comparing the behavior of the woman's children with any other children's behavior, perceptibly such behavior could be normal among all children, especially when there is more than one. It is another way of expressing his aversion to the woman. A. Nünning suggests that "syntactic signals denoting the narrator's high level of emotional involvement, including exclamations, ellipses, repetitions, etc." challenge the credibility of the narrator. To surmise, the narrator's account of the events sounds to be distorted, projecting textual signs of the critical position of the narrator who is ultimately materialized as unreliable.

As the recall goes on, the narrator attempts to capture the definite voice of a more subjective mode of presentation, through the predominant deployment of direct speech and the occasional use of free direct speech, in all his face-to-face encounters with the young couple (see Banfield, 1982, on discussion of subjectivity and speech presentation). This subjectivity increases when he further presents the proclaimed "rumors" about the couple:

You hear Rumors [....] He just didn't look the sort who'd do something really criminal [....] The woman was a dope addict, so this story went, and the husband had brought her up here to help her get rid of the habit [....] Sallie Wilson from the welcome wagon. She dropped in on them one afternoon and said later that, no lie, there was something funny 
about them - the woman, particular [.... Well, just the way her eyes looked if you came up close to her, Sallie said. (Author emphasis p. 85-86)

When a piece of narrative is displayed subjectively through the eye of its first person, all events, beliefs and perceptions are cautiously filtered through his/her idiosyncrasies. The narrator uses subjective narration to separate himself from the community as a whole and describes the rumors from his position as an ordinary hearer. Likewise, the narrator holds controversial values and concepts, forcing the reader (whom he directly and repeatedly addresses) to take part in his narrative and challenge and test his own perspectives. The narrator distances himself from the first-person narrator and alludes to the subjectivity in order to drag the prospective reader "you" (whom he repeatedly addresses directly) to take part in his narrative. From this vantage point, the narrator uses the thoughts of other characters as a lens in order to receive and interpret events. The narrator holds controversial values and concepts, forcing the reader to challenge and test his own perspectives. The events of these rumors are pieced together and presented as a speculation which helps to realize a clear insight into the narrator's motivation. Apparently, these rumors mirror closely his own perception of the contrasting pictures of young couple, the man as being good-for-nothing as well as victim and the woman as being a negligent mother. In other words, such rumors add nothing except reinforcing his ongoing conception about the couple. For instance, taking a quick look at the account of the rumors, inconsistencies appear overtly. The rumor associated with the woman being a dope addict, and her husband bringing her to help her get rid of the habit is in direct contradiction to his constant criticism against them for being out of work. Although the narrator tries to isolate himself from such rumors, the whole account represents his biased contention and accusations, conveying his negative position against the young couple. Readers can make sense of the assorted contradiction pertaining to the fact that he is seen through many different ways of fallible and subjective perspectives. What is interesting in this analysis is that it projects a further set of signs of his narratorial unreliability, as explained by A. Nünning in these words "an accumulation of remarks relating to the self as well as linguistic signals denoting expressiveness and subjectivity" are an indication of unreliable narration.

Generally speaking, the reliability of the narrator's story about the couple is unsteady because what might be argued here is that the narrator seems to have gone through hard experiences and usually has been changed by them. It seems to me that the narrator is trying by all means to portray obliquely his failure in his life by presenting the life of this couple from his own perspective and through repeating their faults. In other words, he seems to be taking this couple as a scenario in attempting to reveal his own life story. Let us look back again at the paragraph where the narrator presents his identity, and also take into account his incongruities about his conception of the value of work in a man's life as discussed above; we can observe that there is a lot of resemblance between the narrator's life and the life of the couple, particularly, in relation to broken faith in the marriage life. To put it differently, within his apparent inconsistencies, he tries to mask certain feelings concerning his past life for there is a clash between what he narrates and the interpretation that he offers us to consider.

However, though the inferences I have made to fill in further information from my general knowledge and experience seem to be convincing, another theoretical issue is raised, that is, the issue of point of view. From an analytic point of view if my conclusion that the narrative seems to be self-focused, then interestingly it belies the first sentence of the story where the narrator declares: "This has nothing to do with me". This observation tends to be disenchanted hence worth some analysis. Lyons (1977) argues that:

the demonstrative 'this' and 'that' 'include a number of subjective facts (such as the speaker's dissociation of himself from the event he is referring to) which are non-proximity, but are difficult to specify precisely. (p. 668)

Toolan (1995), on the other hand, explains that:

the narrators of Carver's acclaimed and allegedly 'minimalist' fiction: characters' values and preoccupations and kinds of hurt are not declared directly in what they say and do, but only indirectly, via what is presupposed by what they say and do. (p. 133)

Toolan's prediction is accurate enough to support my argument that what is involved here is more than just a simple story about a young couple, rather it is the life story of the narrator himself. What is more, "contractions between the narrator's explicit comments on other characters and her implicit characterization of herself" (A. Nünning) cast shadow over the narrator's reliability.

Based on the critical observation I have discussed so far, I can assert that in order to produce a fruitful analysis for such an intractable text that is crammed with different sorts of stylistic features, a reader, from my point of view, should be familiar with a choice of stylistic analytical tools and be able to apply them in the textual analysis of the text. The first of which is, as discussed above, the awareness of the concept of the narratorial unreliability which enables us to obtain insights into the subtleties of the incongruities and peculiarities deployed in the main narrative, and the second of which is exploring how repetition works in the text and what kind of effects it produces.

\section{CONCLUSION}

To sum up, this paper critically re-examines Carver's short story "What Do You Do in San Francisco?" It has been argued that to provide a better account of understanding Carver's text is to account for the affective stylistic means used by Carver. The outcome of the analysis gives an outlook on how the repetition of the five portions of the narrative, through five key words, and the utilized rhetorical strategies, stand out from their surrounding and bring the narrator's 
world into focus, evoking a world behind the surface world of the narration that needs to be explored comparatively as it offers an alternative way of examining the story. Furthermore, this paper has shown how using A. Nünning's theory of detecting unreliability provides the reader with signs about the existence of the manifold textual inconsistencies and contradictions which emerge noticeably on the surface of the story, leading the readers to work out an alternative meaning within its depth. After all, this study remains relatively under-researched but it provides a promising area of further research.

\section{REFERENCES}

[1] Al-Mansoob, H. (2004). "What Do You Do in San Francisco?" text worlds in Raymond Carver. Unpublished paper presented at the annual convention of PALA, New York, July.

[2] Al-Mansoob, H. (2010a). From her perspective: language, style and cognition in the foregrounded present-tense narrative of Raymond Carver's "Fat". Journal of Language and Literature 3, 85-92.

[3] Al-Mansoob, H. (in press). The present tense in the text world of Truman Capote's "A Christmas Memory": a cognitive perspective. Journal of Ibb University Researcher.

[4] Banfield, A. (1982). Unspeakable sentences: narration and representation in the language of fiction. Boston: Routledge \& Kegan Paul.

[5] Booth, W. (1961). The rhetoric fiction. Chicago: Chicago University Press.

[6] Booth, W. (1974). A rhetoric of irony. Chicago: Chicago Univ. Press.

[7] Booth, W. (1983). The rhetoric fiction. 2nd ed. Chicago: Chicago University Press.

[8] Campbell, E. (1992). Raymond Carver: a study of the short fiction. New York: Twayne.

[9] Carver, Raymond. (1993). "What Do You Do in San Francisco?" Will You Please Be Quiet, Please? Raymond Carver. New York: McGraw-Hill.

[10] Chatman, S. (1978). Story and discourse: narrative Structure in fiction and Film. Ithaca, NY, and London: Cornell University Press.

[11] Chatman, S. (1990). Coming to terms: the rhetoric of narrative in fiction and film. Ithaca, NY: Cornell University Press.

[12] Chenetier, M. (1986). Living on/off the 'Reserve'. In M. Chenetier (ed.), Critical Angles: European views of contemporary American literature. Carbondale: Southern Illinois UP, 165-90.

[13] Cohn, D. (2000). Discordant narration. Style 34.2, 307-16.

[14] Cornwell, G. (2005). Mediated desire and American disappointment in the stories of Raymond Carver. Critique 46.4, $344-56$.

[15] Culler, J. (1975). Structuralist poetics: structuralism, linguistics and the study of literature. London: Routledge.

[16] D'hoker, E. (2007). The unreliable Ripley: irony and satire in Robert Mcliam Wilson's Ripley Bogle. Modern Fiction Studies 52. 3, 460-477.

[17] D'hoker, E. and Gunther M. (eds.) (2008). Narrative unreliability in the twentieth-century first-person novel. (Narratologia, 14). Berlin and New York: Walter de Gruyter.

[18] Emmott, C. (2002). Responding to style: cohesion, foregrounding and thematic interpretation. In W. van Peer (ed.), Thematics: interdisciplinary studies. Amsterdam/Philadelphia: John Benjamins, 91-117.

[19] Facknitz, M. (1992). Raymond Carver and the menace of minimalism. In C. Ewing (ed.), Raymond Carver: a study of the Short Fiction. New York: Twayne.

[20] Fludernik, M. (1996). Towards a 'natural' narratology. London: Routledge.

[21] Gentry, M. and Stull, W. (1990). Conversations with Raymond Carver. Jackson: UP of Mississippi.

[22] Hansen, P. K. (2007). Reconsidering the unreliable narrator. Semiotica 165.1/4, 227-246.

[23] Henning, B. (1989). Minimalism and the American dream: 'Shiloh' by Bobbie Ann Mason and "Preservation" by Raymond Carver. Modern Fiction Studies 35.4, 689-98.

[24] Herzinger, K. (1985). Introduction: on the new fiction. Mississippi Review 40-41, 7-22.

[25] Johnstone, B. et al. (1994). Repetition in discourse: a dialogue. In B. Jonhstone (ed.), Repetition in discourse: interdisciplinary perspectives (Vol.1). Norwood, NJ: Ablex, 1-20.

[26] Kindt, T. and Müller, H.H. (2006). The implied author: concept and controversy. (Narratologia: contributions to narrative theory, 9). Berlin and New York: Walter de Gruyter.

[27] Labov, W. (1972). The transformation of experience in narrative syntax. In W. Labov (ed.), Language in the Inner City. Philadelphia: University of Pennsylvania Press, 354-96.

[28] Lanser, S. (2001). (Im)plying the author. Narrative 9, 153-60.

[29] Lyons, J. (1977). Semantics (Vols. 1\&2) Cambridge: Cambridge University Press. 1977.

[30] Meyer, A. (1999). Now you see him, now you don't, now you again: the evolution of Raymond Carver's minimalism. Critique 30, 239-51.

[31] Miall D. and Kuiken, D. (1994a). Foregrounding, defamiliarization, and affect: response to literary stories. Poetics 22, $337-407$.

[32] Nesset, K. (1995). The stories of Raymond Carver: a critical study. Athens: Ohio University press.

[33] Nünning, A. (1993). Renaissance eines anthropomorphisierten Passepartouts oder Nachruf auf ein literaturkritisches Phantom? Überlegungen und Alternativen zum Konzept des 'implied author.'"Deutsche Vierteljahresschrift für Literaturwissenschaft und Geistesgeschichte 67, 1-25.

[34] Nünning, A. (1998). Unreliable Narration zur Einführung: Grundzüge einer kognitiv-narratologischen Theorie und Analyze unglaubwürdigen Erzählens." Unreliable Narration: Studien zur Theorie und Praxis unglaubwürdigen Erzählens in der englischsprachigen Erzählliteratur. Ed. Ansgar Nünning. Trier: WVT, 3-40.

[35] Nünning, A. (2008). Reconceptualizing the theory, history and generic scope of unreliable narration: towards a synthesis of cognitive and rhetorical approaches. In E. D'hoker and M. Gunther (eds.), Narrative Unreliability in the Twentieth-Century First-Person Novel,(Narratologia, 14). Berlin and New York: Walter de Gruyter, 29-76. 
[36] Nünning, V. (2004). Unreliable narration and the historical variability of values and norms: the Vicar of Wakefield as a test case of a cultural-historical narratology. Style 38. 2, 236-252.

[37] Olson, G. (2003). Reconsidering unreliability: fallible and untrustworthy narrators. Narrative 11.1, 93-109.

[38] Rimmon-K., Sh. (1983). Narrative fiction: contemporary poetics. London: Routledge.

[39] Runyon, P. R. (1992). Reading Raymond Carver. New York: Syracuse University Press.

[40] Saltzman, A. (1988). Understanding Raymond Carver. Columbia: University of South, Carolina Press.

[41] Scofield, M. (1999). Story and history in Raymond Carver. Critique 40.3, 266-251.

[42] Short, M. (1996). Exploring the language of poems, plays and prose. London: Longman.

[43] Tannen, D. (1987a). Repetition in conversation as spontaneous formulaicity. Text 7, 215-43.

[44] Toolan, M. (1995). Discourse style makes viewpoint: the examples of Carver's narrator in "Cathedral." In P. Verdonk and J. J. Weber (eds.), Twentieth Century Fiction: From Text to Context. London: Routledge.

[45] Wall, Kathleen. (1994). The remains of the day and its challenges to theories of unreliable narration. Journal of Narrative Technique 24, 18-24.

[46] Wolfson, N. (1978). A feature of performed narrative: the conversational historical present. Language in Society 5, 215-37.

[47] Wolfson, N. (1979). Conversational historical present alternation. Language 55, 168-82.

[48] Yacobi, T. (1981). Fictional reliability as a communicative problem. Poetics Today 2, 113-126.

[49] Zerweck, B. (2001). Historicizing unreliable narration: unreliability and cultural discourse in narrative fiction. Style 35.1, 151178.

Huda Al-Mansoob was born in Ibb, Yemen, she received her BA in English from Sana'a University, and then she received her $\mathrm{MA}$ and PhD in cognitive discourse analysis from Nottingham University, England, in 2006. She is working as a lecturer at Ibb University. In 2008, she was appointed as head of the English department and currently holds the position of Dean of the center of Languages and translation. Her research interests lie in discourse analysis, cognitive stylistics/poetics, Text World Theory, style and translation and modern literature. 